\title{
PREVENTING RADICALISM THROUGH INTEGRATIVE CURRICULUM AT HIGHER EDUCATION
}

\section{Saca Suhendi}

Univeritas Islam Negeri (UIN) Sunan Gunung Djati Bandung

Jl. A. H. Nasution No. 105, Bandung, Jawa Barat, Indonesia, 40614

Email: sacasuhendi@uinsgd.ac.id

\section{Wagdy Abdel-Fatah Sawahel}

National Research Center, Cairo, Egypt

El Buhouth St., Dokki, Cairo, Egypt, 12622

Email: sawahel@hotmail.com

\section{Kafil Yamin Abdillah}

Univeritas Islam Negeri (UIN) Sunan Gunung Djati Bandung

Jl. A. H. Nasution No. 105, Bandung, Jawa Barat, Indonesia, 40614

Email: yamin.kafil865@gmail.com

Received: 04, 2020. Accepted: 06, 2020. Published: 06, 2020

\begin{abstract}
Religious radicalism which spread across the globe has turned into a global problem and raised concern among scholars to discuss. Higher education institutions which are supposed to educate cadre of high intensity scholars on an empirical level have to some extent failed to meet the expectation. In Indonesia, some of the institutions have been deemed as a place of metamorphosis for potential site to nurture radicalism understanding and movement among their students on campus. This paper was aimed at investigating university effort to join the global struggle against radicalism. This study applied descriptive qualitative research using survey methods. Data were collected using observation techniques, interviews, and documentation. Using the theory of positive radicalism which demands transformation with a comprehensive religious understanding, this study analyzed the data. The results of the study show that the phenomenon of radicalism at higher education can be handled by implementing integrative curriculums as one of the feasible ways for higher education institutions to participate and establish their role. Integrative curriculum can be applied to catalyze new energy to present a more comprehensive and tolerant atmosphere by emphasizing the role of Islam in building world civilization.
\end{abstract}

Keywords: Integrative Curriculum, Islamic Universities, Radicalism, Religious Moderation, Virtual University

\begin{abstract}
ABSTRAK
Radikalisme agama yang menyebar di seluruh dunia telah berubah menjadi masalah global dan menimbulkan keprihatinan di antara para sarjana untuk dibahas. Lembaga pendidikan tinggi yang seharusnya mendidik kader sarjana intensitas tinggi pada tingkat empiris sampai batas tertentu gagal memenubi harapan. Di Indonesia, beberapa lembaga telah dianggap sebagai tempat metamorfosis untuk situs potensial untuk memelihara pemabaman dan gerakan radikalisme di antara mahasiswa mereka di kampus. Makalah ini bertujuan untuk menyelidiki upaya universitas untuk bergabung dengan perjuangan global melawan radikalisme. Penelitian ini menggunakan penelitian kualitatif deskriptif dengan menggunakan metode survei. Data dikumpulkan dengan menggunakan teknik observasi, wawancara, dan dokumentasi. Menggunakan teori radikalisme positif yang menuntut transformasi dengan pemahaman agama yang komprehensif, penelitian ini menganalisis data. Hasil penelitian menunjukkan bahwa fenomena radikalisme di pendidikan tinggi dapat ditangani dengan menerapkan kurikulum integratif sebagai salah satu cara yang layak untuk berpartisipasi dalam institusi pendidikan tinggi. Kurikulum integratif dapat diterapkan untuk mengkatalisasi energi baru untuk menghadirkan suasana yang lebib komprehensif dan toleran dengan menekankan peran Islam dalam membangun peradaban dunia.
\end{abstract}

Kata Kunci: Kurikulum Integratif, Moderasi Beragama, Radikalisme, Toleran, Universitas Islam, Universitas Virtual 


\section{INTRODUCTION}

Religious radicalism is blamed as a frightening 'monster' in the era of globalization, along with many violent actions taking place in the name of religion for certain purposes. It has been stigmatized because prominent actors in acts of violence in the name of religion are generally carried out by a group of Muslims. Acts of violence in the name of religion are stigmatized to make changes by means of violence. (Hasani \& Bonar, 2012). This was reinforced by Azra (1999) that religion is a land to become a crying banner in carrying out radical actions based on the reading and construction of textuality in religion. The same view was stated by Crawford (2001), that religion is easily dragged into the area of radicalism which is based on weak political systems and institutions in a region (state).

Religious radicalism, as a general phenomenon, in each religion emerges and it is closely related to the reality of the variety of interpretations, ideas, schools of thought, denominations, and religious sects within a particular religion. Radicalism in the case of Islam, for example, stems from a literal and ad hoc understanding of the verses of the Qur'an (interprettation of the meaning of jihad). (Khamdan, 2015) This kind of literal religious text understanding hardly provides space to accommodate and compromise with other moderate Muslims understanding.

Another factor contributing to religious radicalism is related to the euphoria of freedom. Each person or group feels that they have their freedom to express. Political and social fragmentation among political elites, social elites, and elites has an impact on the grassroots and they lead to horizontal and latent conflicts. They contribute to the growth and fertility of religious radicalism among social groups (Rahmatillah, 2007; Asrori, 2015). In addition, inconsistencies in upholding legal supremacy, disorientation and dislocation in Indonesian society on the grounds of economic difficulties and livelihoods are the main sources triggering the emergence of religious radicalism. (Rahmatillah, 2007; Asrori, 2015). According to Jati (2013), radicalism in the study of populism, does not always produce violence and extremism. Aggressive actions among populism which are often dubbed radicalism committed by some Muslims against authoritarian regimes are strategies to free themselves from authoritarian power. Radicalism arises from a spirit of liberation so that Muslims could cope with economic inequality and political marginalization (Bötticher, 2017).

In Indonesia, religious radicalism movement has actually developed since the Dutch colonial era. (Mubarok \& Hamid, 2018) The movement has been generally affiliated with the Salafi movement in the Middle East. The Salafi movement which made its progress in the XII century Hijri was developed by Abdul Wahab (1703-1787) in Saudi Arabia with the orientation of purification of Islamic teachings (back to the Qur'an and Hadith). However, the Salafi movement in its development did not merely carry out religious purification (aqeedah) movements, but it went further by exploring the intellectual and political dimensions (Laisa, 2014) It seems that educational factors, in addition to the factors that have been mentioned, has led a person to easily accept religious information from people they have considered highly knowledgeable (Asrori, 2015; Sarie, \& Mariamah 2013). Hassan's research (2013) states that radicalism among Muslims is framed in the perspective of westernization and historical perspective. The religious radicalism movement among Muslims is now growing in the Hizb ut Tabrir Indonesia (HTI) community organizati-on as explained in Muzakki's research (2014) and (Robingatun, 2017).

The rise religious radicalism with its broad influence in social, economic and political life in the era of globalization has finally become a serious concern among scholars and researchers. Research by Schoeck et al. (2015) and Tina (2017) in his work entitled Rise of Religious Radicalism in the Arab World: Significance, Implications and Counter Strategies explains in detail the emergence of radical religions in the Arab world which has a wide impact 
on perpetrators of violence in the world. Other research was conducted by Rink and Sharma (2018) who investigated factors which triggered religious radicalism in Africa, especially Kenya. Veldhuis \& Staun (2009) examined the radicalization of Islam which specifically explains the root cause model of radicalism that developed in the global era. A number of other studies explain the same results that religious radicalism in the general population, inclusive of Muslims, as stated by researchers is not caused by a single factor, but rather the accumulation of factors, such as religious perspectives, social situations, the economy, law enforcement and education factors (Yusar, 2016; Taufik, 2019; Sadiah, 2018; Muchith, 2016). The Change Institute Team (2008) examined factors in technological development contributing to radicalism, as explained in the writings of Behr, et al. (2013).

Religious Radicalism has been connected with the educational factor. Educational institutions are apparently not free from the influence of radical understanding. Some Indonesian students, although few in number compared to students from Europe, America, Asia and Africa, are involved in international radical movements affiliated with the Islamic State of Iraq and Syria (ISIS). The National Agency for Handling Terrorrist (BNPT) released that the level of student involvement in radicalism is very worrying. According to its report, students are very potential to be targeted by radical religious ideologies (Suharto \& Assagaf, 2016). The results of the BNPT report has been corroborated by Nur Syam in Suharto \& Assagaf (2016) research which investigated the exponents of the radical Islamic organization movement had targeted students in all faculties and study programs. A number of findings of student involvement, especially PTKIN (State Indonesian Islamic Higher Education), for example the arrest of STAIN Surakarta students in the Antiteror 88 Detachment Team Police raid at the end of 2005. Five years later, precisely in 2010, two students of a private university in Sukoharjo, were arrested by the Special Antiterror 88 Detachment Team because of their allegedly involvement in terrorism networks. Based on the research conducted vy the CSRC (Center for Study of Religion and Culture) of UIN Syarif Hidayatullah Jakarta in 2010, there were three mosques out of 10 mosques in Surakarta that had been used as the basis for spreading religious radicalism (Tahir, 2015; Robingatun, 2017).

Radicalism among students in terms of their (religious) thinking in a positive sense is fine, as long as they are not embraced by anarchism that harms the life of the nation and state. Usually, radicalism has been associated with to two ideologies, namely religion and nation (in Indonesia is simplified to the relationship between religion and Pancasila). There are some students who accept well the relationship between religion and the state (Pancasila as religious ideology) research (Aseri, 2015). On the other hand, some students on a number of campuses show the opposite findings on their behaviors.

Education or educational institutions have the potential to spread radicalism among students and they have been proven that there are some university students who are involved in radical actions. This is due to several factors. One of them is related to student activities outside of learning activities on campus (such as discussion groups) and learning activities on campus, especially related to curriculum and learning approaches that apply in universities in Indonesia.

To date, there has been no specific research related to the level of curriculum influence on radicalism among students. However, based on a serious study of the curricula prevailing in Indonesia, especially at PTKIN, curriculums with an atomistic (partial) paradigm are strongly suspected to be one of the fundamental factors of religious understanding in universities (Abdullah, 2004). Integrative paradigm curriculum has been hailed as an alternative to overcome rigid, and fundamentalist views, thoughts and behaviors. Referring to the view of Abdullah (2007), curriculum that has an integrative, circular paradigm (interconnected entities) of a model an academic approach that seeks to respect one another in the sense that general 
science and religious science are aware of each other's limitations in solving human problems. This may pave the way to a collaboration, at least understanding each other's approach (method) and method of thinking (process and procedure) between the two. The curriculum of the atomistic paradigm has shaped to a worldview which is rigid (Abdullah, 2010). The integrative curriculum is expected to shape non-rigid framework which can be described by the metaphor of mercury lamps that has its gradual characteristics not sudden one. It can support the moderation in religion program.

In relation with curriculum, there is a study conducted by Rustam, et al. (2018) investigated the implementation of the 2013 curriculum. The study examined an integrative approach in its implementation. The curriculum has shown its effectiveness in preventing the flow of radicalism, even though it is only limited in schools. There is a lack of studies investigating the integration of curricula in higher education institutions in preventing radical thought and movement. This study tries to fill the gap.

\section{METHOD}

This research is a qualitative study that explains the relationship of students in the network of global and national radical movements in promoting ideological Islam in the sociopolitical arena. The data were collected using documentation study and observations of the phenomenon of radicalism in public universities. This documentation technique is actually related to some important writings about activities on campus, especially by students (literature study). Literature study aims to provide an assessment of empirical findings from survey data. This assessment is done by comparing with concepts or various theories that are relevant in the scope of sociology, politics, and Islamic studies.

\section{RESULTS AND DISCUSSION \\ Radicalism in Indonesia Student Involvement Factors}

Radicalism in this paper is interpreted as a radical religious movement (Islam) among students who aspire to make major changes in the socio-political agenda. The methods used are often extreme and cannot be accepted by others. However, in this paper radicalism is closely related with the term fundamentalism as an understanding that tries to fight for or apply what is considered fundamental. The struggle is then framed in a methodological framework that contains principles: oppositionism, rejection of hermeneutics, rejection of pluralism and relativism, rejection of historical and sociological developments. One of the jargons of the fundamentalists, that the historical and sociological development has brought people further away from the literal doctrine of the holy book. It is interesting to talk about the process of radicalization reaching campuses, especially among their students.

Throughout history, students in various countries have played an important role in the history of their countries. In Indonesia, in May 1998, hundreds of thousands of students succeeded in forcing President Soeharto to step down from his position. BNPT released that the level of student involvement in radicalism is very worrying. Students are very potential to be targeted by radical religious ideologies. Its findings regarding the involvement of this radical movement network are directly proportional to Nur Syam Nur Syam's view that exponents of the radical Islamic organization movement have reached students in all faculties and study programs (Suharto \& Assagaf, 2016). The Ministry of Religion Research and Development in 1996 conducted a study that reported four secular universities --- UI, UGM, Unair and Unhas --- had seen the increased religious activities in those campuses, and became the most potential place for developing Islamic (religious) activities which tends to be exclusive and radical. 
The stigma of higher education as a place of grooming radical movement is evident when Anti-Terrorism Detachment 88 Police Headquarters Team at the end of 2005 arrested STAIN Surakarta students. Five years later, precisely in 2010, two students from a private university in Sukoharjo, were arrested for allegedly being involved in a terrorism network (Suharto \& Assagaf, 2016). Islamic tertiary institutions in the Jakarta area were shocked by the students' involvement when five out of 17 members of the Pepi Fernando network, three of them graduated from Syarif Hidayatullah State Islamic University (UIN) Jakarta (Safiudin, 2011). Other three students were arrested and one of them was from the Faculty of Science and Technology (UIN) Syarif Hidayatullah Jakarta.

Research conducted in 2011, in Malang, East Java reported that nine students of the University of Muhammadiyah Malang (UMM) were victims of brainwashing by a heretical and illegal organization. UMM stated that the nine students were registered as engineering and health faculty students in 2010 who were recruited by organizations on behalf of NII. Radical Islamic groups have dominated campus student activities. Their influence reached ITS (Surabaya Technology Institute), UNAIR Medical Faculty (Air-Langga University), UNTAG (Seventeen August University), UIN Surabaya and others. They used LDK (the campus missionary institution) to nurture radicalism and and they had a national and international network

Taking into consideration radicalism supporting factors, there are at least two factors which can be related with radicalism among students. First, there have been changes in religiously based universities. Along with the development of global demands, religious universities (Islam) are transforming into universities, IAIN/STAIN to UIN --- institutional and academic --- which opens great opportunities for high school alumni to enrol at these universities. Unlike UIN, IAIN status is still only accepting prospective students from Madrasah Aliyah (MA) graduates or graduates from Islamic boarding schools. Secondly, there has been a metamorphosis of forms and strategies in the internal radical movements. The Islamic movement developed around the campus in the mid-1970s, which was first initiated by the Salma Mosque at the Bandung Institute of Technology (ITB). On that campus there was a Da'wah organization called LMD (Da'wah training) which forms an exclusive Da'wah group called "usrob" or small groups.

LMD, whose emergence coincided with the repressive regime of the New Order. It had a "negative" attitude towards Islamism and acted as a counter to the issue of the secularization idea put forward by Nur Cholis Madjid. It promoted the teachings of "Islam kaffah " which refers to the thoughts of fundamentalists in the Middle East, such as the ideas of Hasan alBanna, Sayyid Qutb, and others. While the idea of Islam kaffah was introduced as a basic principle, its derivatives included doctrines that emphasized the superiority of Islam over other ideologies. The LMD program also instilled other Islamic principles to return to the Qur'an and the Hadith, and the urgency of upholding monotheism as the basis of life from simple aspect to most complicated field like social, economic and legal systems.

This Islamist supporter used the mosque as a center for preaching activities. Islamic studies in campus mosques, especially in Salman Mosque were oriented towards advocating Islamic leadership to change the social order to conform to the teachings of Islam as a totality. Islamic leadership is needed to form a society ruled by Islamic law. The ideas of Islamism that were nurtured at the Salman Mosque then spread into other campuses in Indonesia. The network was developed by LMD alumni. This network was categorized as OTB (not forming a structural organization) and they were established by common ideology. Islamist ideas began to be studied in other campus mosques such as the Saladin mosque, UGM and the Shuhada Mosque, Arif Rahman Hakim (ARH) mosque, UI, and others. The Islamist movement of students in Islamic tertiary institutions (PTKIN) is strongly suspected to have emerged along 
with the Islamist movement on campuses in the public tertiary institutions using campus mosques as the place for their activism. LMD activity on several campuses has put the role of Indonesian Islamic Association (HMI) student movement into a minor one.

There are two reasons accounted to the emergence of LMD movement which subsequently gave birth to other movements in the form of Tarbiyah Islamiyyah or Hizb utTahrir and its affiliated movement. First, the adoption of a single principle by the New Order regime to all political and social organizations had forced Islamic activists to find a way to maintain the Islamist ideology and even instilled it among Muslim youth. Campus is a strategic choice. Second, the NKK/BKK (a policy to normalize campus life) policy, which was launched by the New Order regime, precisely fostered new activism among students in the form of study groups. One of them is an Islamic discussion group based at the campus mosque, a place which was safe enough from government suspicion.

The excitement of Muslim students to get involved in Islamic studies in campus mosques was also driven by the lack of Islamic learning opportunities found in classrooms, especially in public universities. Taking into account its ideological point of view, campus Islamism that was inspired by the hardliners did not expressly show a radical face. There is a hypothesis that explains that the idea of Qutb, a radical fundamentalist might be read and discussed in the Usroh or Tarbiyah studies, there is no strong evidence that shows the manifestation of Islamism in a radical form. There is no Islamist movement that originates from the campus circles who openly disbelieve the authorities for not implementing Islamic law. They also did not call their members to strive to overthrow the legitimate government to be replaced by a total Islamic government that runs the Shari'ah. The shift from moderate Islamism to radicalism as happened in Egypt and Jordan did not occur in Indonesia. In Indonesia, the post-Soeharto era showed a tendency for new-Islamism whose figures were involved in the constitutional political arena and at the same time they are promoting the essence of Islamic teachings through public policy making.

\section{Preventing Religious Radicalism on Campuses}

Radicalism as a religious understanding is dangerous, especially when it leads to radical movements within the campus. To overcome this problem, a solution is sought by stakeholders in higher education. Higher education stakeholders applied the effort through learning activities and outside learning activities. In connection with learning activities, the application of curriculum with integrative thinking paradigms has been implemented in a number of higher education institutions.

\section{Integrative Curriculum}

The curriculum with the paradigm of integrative thinking in a number of universities has so far been introduced along with the transformation of colleges from institutes/colleges to universities. The universities in accordance with the paradigm of scientific development, have carried out an integrative curriculum. The integrative curriculum promotes discussion on each discipline which has universal truth. At PTKIN, the integrative curriculum embodies Islamic discipline to discuss with its counterpart, secular science, such as sociology, anthology, philosophy, physics, cosmology, chemistry, biology, and vice versa. In this context, KKNI (The Indonesian National Qualification Framework Based Curriculum) has represented the integrative curriculum.

This integrative curriculum in learning includes four levels, namely the philosophical, the material, the strategy and approach, and the evaluation level.

\section{Integrative Curriculum at the Philosophical Level}

Integration of the curriculum at the philosophical level indicates that each study of subjects needs to be given a fundamental value in relation to other scientific disciplines and in 
relation to humanistic values. Figh learning, for example, in addition to its fundamental meaning as a philosophy of building relationships between humans, nature and God in Islamic teachings, needs to be instilled in students that the existence of Figh is not independent or self-sufficient, but develops together with other scientific disciplines such as philosophy, sociology, psychology and more. Learning sociology - as a general science - which studies social interaction between humans becomes empowered properly if the lecturer of sociology is able to motivate students to review social interaction theories that already exist in cultural and religious traditions. UIN Sunan Kalijaga has built integrative curriculum at a philosophical level as stated in the Academic Working Group of UIN Sunan Kalijaga Yogyakarta. The integrated curriculum of UIN Sunan Kalijaga Yogyakarta is described in a metaphor of integrated-interconnected web of spiders. UIN Syarif Hidayatullah, even though it does not explicitly mention it, but has had a degree of unity in the integration of knowledge. UIN Maulana Malik Ibrahim introduced the popular metaphor "tree of knowledge" in describing scientific integration.

The integrative curriculum at this level requires every course to have universal values that can facilitate a dialogue, debated with scientific principles, communicated in learning activities, so there is no claim that religious science is "the great" and deserves to be studied only or vice versa.

\section{Integrative Curriculum at the Material Level}

The integrative curriculum at the material level confirms that the material in each course has a universal truth that needs to be met. Material level is a process of integrating universal truth values generally with Islamic studies specifically into social sciences such as physics, chemistry, biology, medicine, philosophy, anthropology, sociology, law, politics, psychology, economics, education and so on. Integration of the material level also means bringing together these general sciences into Islamic studies, by integrating them through epistemological and axiological dimensions. A number of universities in the PTKIN environment have integrated into this level of material, although it has not been exhaustive. UIN Sunan Kalijaga with the scientific paradigm developed by Amin Abdullah through the metaphor 'Spider Web' has implemented this material level integrative curriculum. UIN Maulana Malik Ibrahim Malang presents an integrative curriculum with the 'Tree of Science' metaphor, followed by UIN Sunan Gunung Djati Bandung with the metaphor 'Pedati Wheel', UIN Semarang carries the model 'Twin Towers' and so on. For example, the learning of Islamic philosophy dialogue with philosophical thinking and modern philosophy, both philosophies that developed in the West and in the East. Jurisprudence at this level is carried out through theoretical hybridization efforts between Islamic law by introducing national law and its contextualization. Reading materials used as references for lecturers and students are presented in books, journals in an integrative-interconnected manner.

\section{Integrative Curriculum at the Strategy/Learning Approach Level}

The integrative curriculum at the level of research methods and approaches confirms that each science has a unique research methodology commonly used in scientific development. Psychology, for example, has distinctive methods such as introspection, extrospection and retrospection, in addition to other general methods; questionnaire, interview, and observation. The methodology as explained by Assegaf $(2013,2014)$ can be expanded in terms of approach. For example, in contemporary psychology known as phenomenological, contemplative, and normative approaches. These approaches in the context of the scientific structure of the state Islamic university (UIN) are integrated and interconnected with other disciplines. Psychology with Islamic values, methodologically uses a safe approach for this knowledge. A phenomenological approach that gives empathetic appreciation from people who experience it directly is considered safer than other approaches 
that contain anti-religious biases. For example, the psycho-analysis approach is integrated with the phenomenological approach.

This integrative curriculum in the area of methodology and research approach also emphasizes that serious scientific theory in its implementation needs to be supported by rigorous research. Lecturers need to encourage their students to conduct research on related subjects so that their knowledge is dignified. FPI (Islamic Education Philosophy Course) which applies a deductive mindset (truth in Islam) is then seen from phenomena in society. The inductive mindset, (based on various educational cases) is connected with norms in Islam. Philosophy learning strategies, besides contemplative thinking, also uses a dialogue strategy between students and lecturers. According to Assegaf, (2011) the research method has been inherent in its scientific discipline, such as the method of philosophical research that has been embedded in the FPI course. Thus, the FPI course within the framework of the concept of research-based knowledge needs to contain aspects of research both at the material level and learning strategies. Integration of the curriculum in the level of strategy and research approach, although named differently, most Islamic universities have implemented a strategy and approach integration in learning.

The integrative curriculum at the strategy level is a continuation from the material level. While integration in the material level shows the material presented in the learning process, the strategy level is the stage of implementing learning by applying various models and learning methods. Active learning with various models and methods has been carried out by a large number of lecturers at PTKIN in certain levels. When lecturers face limitations in their implementation, team teaching is formed by synergizing lecturers across scientific fields so that integrative learning takes place. Assegaf (2014) explained, the more scientific disciplines integrated in a learning process, the more varied learning strategies needed and involving many lecturers to teach the field of study being studied. Studying the subject of of Figh, for topic of ablution material, for example, lecturers can exchange ideas interactively with students about the substance of ablution and also convey important values in the transformation of social life. The health value of thinking, liver and physical, body, clothing, environment must be transformed in social life. Thinking clearly must be realized in the form of acting rationally, moderately, and proportionally. In the economics, the law of usury (interest) in learning is conveyed by connecting it with information on banking or credit practice cases that are commonly used as business transactions. The implementation of the casuistic strategy requires lecturer's ability and mastery on banking economic issues which he learned through various economic theories. The learning strategy is presented as the main material in the learning of Islamic Religious Education and is connected with the practice that is found in modern society that is difficult to avoid the world of banks. This may motivate scholars to develop Shari'ah economy which is currently a growing market and industry in national banking.

Integrative curriculum at the strategy level can encourage students to look for various alternative solutions in every problem encountered instead of 'scapegoats' searching and violence acting. Learning by integrating various methods, strategies and approaches can develop students' ability to act wisely, rationally, and constructively.

\section{Integrative Curriculum at Evaluation Level}

The integrative curriculum at the evaluation level as the end of learning activities cannot be relied on only one model. Learning success measures not only the cognitive area, but also affection and psychomotor aspects. Educational evaluation can be interpreted as an assessment activity whose evaluation tool can be either integrated or complementary and non-test. Evaluation using tests is generally carried out in writing in all its forms. Meanwhile, non-test includes rating scales, questionnaires, check lists, interviews, observations, and curriculum vitaes. (Assegaf, 2011, 2013, and 2014). 
Universities relies heavily on using tests that rely on the written results of various sets of questions to assess students. Some experience shows the exams carried out by tertiary institutions, including the UN (National Examination) and UMPT (Higher Education Entrance Examination), both manually and computer-based using written tests. Relying on a clear form of test does not guarantee that the assessment carried out comprehensively. The integrative scientific paradigm always avoids the form of a single test because the results of the evaluation of one form of test does not yet reflect a person's full potential. Other forms of evaluation such as performance, portfolios, projects, reports of parents and peers, a track record of a person's attitudes and behavior are also important to administer to assessed students and achieve comprehensive result. This construction confirms that a rational view with wisdom can form an attitude of rationality. This rational attitude encourages students not to judge others of thinking wrongly and acts violently to resolve differences.

\section{Integrative Curriculum and Religious Moderation in Higher Education}

People in Indonesia have capital to build religious moderation based on their historical facts and sociological reasons. The reality of Indonesian society has been diverse since the beginning of the birth of the Indonesian people, ranging from race, language, culture, and religion. The plurality is maintained by each generation. It can be said that the Indonesian people have been given moderation in various aspects, including moderation in religion. (Akhmadi, 2019) Religious moderation is the fruit of an integrative curriculum by promoting the truth that many in number, even though in God's view there is only one true. It promotes Islam does not teach truth claiming. It does not allow persons to blame and judge people outside themselves and their groups wrong. Along with the policy of the Ministry of Religion of the Republic of Indonesia on religious moderation, campuses, especially in PTKIN, conduct curriculum studies with material that has the potential to lead to radicalism and radicalism. In its practice, the integrative curriculum can bridge the dialogue of "kbilafah" and "jibad" in a more polite and moderate perspective. The lecturers may hold a discussion by applying four levels of integrative curriculum in explaining the terms "kbilafab" and "jihad" so that the terms did not lead to "exclusivism". This practice opposes the fact in the society that the term "khilafah" so far has not been understood properly by most Muslims. The term is limited to historical facts, not as part of figh or sharia. Political battles and power struggles became dominant in the history of the Caliphate.

In addition, the campus supports lecturers and students to conduct studies and writings that have universal values of Islamic teachings, as well as religious moderation. As far as this program is concerned, lecturers at PTKIN conduct research (funded by the BOPTN scheme every year) with the scope building religious moderation. In addition, the Ministry of Religion facilitated the campus in the formation of the House of Relation Moderation. UIN Sunan Gunung Djati Bandung became the pilot project of the Ministry of Religion in realizing the religious moderation agenda. The religious moderation project was signed on November 26, 2019 at UIN Sunan Gunung Djati Bandung. The project is 'Religious Moderation', not Islamic Moderation, which implies that the project applies to all followers of other religions in Indonesia. While each adherent believes that their religion is the truth, but they live under the same state, ideology, law and constitution, where mutual respect is needed (UIN SGD Bandung). The House of Religious Moderation of UIN Bandung is now a training center for lecturers from non-Islamic universities, religious teachers, religious councils, and preachers (priests) as well as a research center for the strategy and implementation of religious moderation. This program in itself refutes the perception which lists the UIN SGD Bandung among radical universities. 


\section{Virtual Campus: Another Effort to Prevent Radicalism}

Based on the explanation the integrative curriculum as a mean to prevent radicalism, it is necessary to see the curriculum paradigm develop in the world of higher education. To date, the curriculum that has been built has both a subjective scientific paradigm and an objective paradigm. The two paradigms have been contradicting each other, especially between supporters of the subjectivism and the objectivism. The first group rely on fideistic beliefs, while the second rely on scientific beliefs in seeing the reality of the diversity of religions. The two paradigms should not be disputed, because religion has two inseparable sides, namely the area of pure-intellectual theory and the practical-empirical area.

There are seven characteristics that indicate the diversity of subjectivism.

1. Looking at others' religious diversity through their religious lens. This normative view is often dogmatic-theological. It says that their religion is the true while the others as untrue. Amin Abdullah (2013) refers to this as opposing reasoning (al-ûuqûl al-mutantâfisah).

2. Full involvement. The demand for a person's full involvement is actually good, but sometimes it goes unnoticed and realized in the element of fanaticism (asabiyyab). If fanaticism has occupied religious diversity, emotion rules. When "emotions" strengthen in certain cases, violent actions cannot be prevented.

3. Observing others' diversity from within (insider). Normative religious patterns can lead to the habits of a religion adherent to see other groups from within their religion. According to Amin Abdullah (2013) insider's position in religion is difficult to train to see other people and groups of people outside themselves through the perspective of outsider with the help of a set of theories, approaches, perspectives, methods, data, etc.

4. Establishing an absolute view. The demand for religious attitudes is certain. Truth and certainty cannot be separated in religion. This certainty is generated and discussed with the term faith. As a consequence of this view, it is rather difficult to distinguish between faith in religion and faith in tradition (belief in religion in the practice of life that has been historical). Other consequences, it is difficult to separate an interpretation of "faith" from individual or group interpretation".

5. Displaying Apologist-defensive. The literature produced by supporters of subjectivism is usually defensive in nature from outside criticism. As the consequences, religious literature tends to be polemic. According to Amin Abdullah (2014), literature and descriptions of polemic-diffused-apological nuances are used as a reason to be produced as a tool to defend themselves from external attacks, both from followers of religion, social-religious researchers and from internal religious communities who happen to be different in scientific perspectives used.

6. Exhibiting Absolutist-non-dialogist. The accumulation of this mindset and attitude lead to mental attitude of human equality that is rigid, hard, absolute, in dealing with various social problems, especially political problems. This non-compromising religious attitude and outlook does not recognize the concept of consensus and appear in its non-dialogical character. Rigid-absolute attitude is indeed needed, because there are insecurities (inscure) both real and created, engineered and accompanied by suspicion and prejudice against anything that comes from outside, especially related to socio-religious issues. Psychologically they always feel that they are in a minority environment, even though in fact part of the majority, and vice versa.

7. Exhibiting Extreme radicals. When the path of compromise and consensus is completely closed and there is no alternative way, religious attitudes turn into the embryo of radicalmilitant-extreme movements. This can be seen in the reality of social life, especially the terrorist acts of the ISIS movement and its affiliates which involve students. 
Religious education in various places in the world generally takes the nuances of education to be "normative-subjective" or also called religious thinking patterns "fideist subjectivism". In this model, learning is only suitable for self and internal groups and is not compatible with the changing world situation. The subjective model of religious education can hardly contribute to the increasingly open world among countries and among the followers of world religions. The subjective model of religious education cannot do anything when confronted with the reality of third parties (stakeholders) who seeks the advantages in the conflict. Interest groups, whether political, economic, social or cultural, always lurk and at times can play with the nuances of subjective-emotional-closed-rigid religions to achieve their interests. Conflicts in various places in the world, including in Indonesia, almost all use religious factors that are normative-subjective in nature as the driving force. In addition, religious groups displaying radical-extremist religious attitudes from various world religious groups that clearly utilize the "emotions" of religious groups that originate from the nuances of normative-subjective-closed religious learning as tools and dimensions of their struggle.

Subjective diversity mindset, teaching model and attitude does not seem conducive to social relations between nations and between followers of world religions on a planet. Religious scientists, especially those struggling in the historical area religions think hard to shift the view of subjectivity to the objectivity of human diversity. Initially, social sciences such as anthropology, sociology, history, psychology play an important role here, then developed into social sciences of religion such as religious sociology, religious anthropology, history of religions. The social scientists of religion want to explain that the reality of religion have not only a subjective dimension, but also has an objective dimension. The social scientists of religions explain and map the fundamental structure of the objectivity of religions, although in historical practice it also depends very much on the "interpretation" of the subjectivity of the actors and leaders. The religious community cannot reject the fundamental structure inherent in the anthropological, sociological and historical reality of these religions. The objectivity of religions can only be obtained by way of conducting in-depth research (research institutions) and tertiary institutions (higher educations) that play an important role in the study of the objectivity of human security.

Unlike subjective religious understanding, Objective religious understanding, among others, is characterized as follows:

1. Descriptive-empirical. Researchers explain objectively the full picture of religion according to its adherents. Then, recorded, classified, categorized, sought a significant relationship between the findings of the data with one another, and interpreted according to the scientific perspective of social studies of religions.

2. Detachment (distance from the object of research). This opposes the views and attitudes that necessitate the need for full involvement and involvement in diversity that is subjective in nature. It entails the ability of researchers and religion scholars to be clear in seeing and observing the structure of religious fundamentals. To avoid and reduce the biases of excessive religious subjectivity (because eliminating them is completely impossible in religious studies, the theoretical framework and research methods are very important.

3. Outsider. Religion researchers and people are no longer trapped by horizons of insider perspectives (as in subjective religions), but at the same time they can play themselves as they can see religion from the outside (outsider). An indispensable tool is related to scientific procedures and mindset, which is called objectivity and theoretical reasoning from religion and does not stop only on the practical reason (amaliab) side. Religious leaders and elite leaders are also required to have an objective attitude (scientific perspectives) in understanding the reality of religions 
4. Historicity. The style of objective religious views is able to distinguish firmly between areas of faith (faith) and tradition (implementation and practice of faith in human history). The historicity of human religiosity is highly considered by the descriptive scientific style of religions. History, culture, and tradition are very important in the science of religion, because all religions since their establishment have formed a long history, strong traditions in their respective environments. This character takes into consideration ritual system (religious anthropology), the origin of religion, change and the development of religion (religious history), the language used as a means of communication (socio-linguistics), and as a pattern social relations of religious communities (sociology) and belief systems or systems of belief (anthropology).

5. Reductionist-relativist. There are criticisms that are directed towards an empirical descriptive approach, among others, an overly excessive emphasis on the outward aspects (externalities) rather than religion. This is understandable, because the religious researchers indeed mostly come from the tradition of positivist social sciences and have not received training on the study of religions that are more comprehensive-humanistic. This deficiency can be solved by the approach of religious phenomenology.

In the study of religions, the subjective (fideistic subjectivism) and objective (scientific objectivism) approaches do not know each other. The normative-subjective study of Islamic religion (and so on) at various levels does not recognize descriptive-historical-objective religious studies. General education under the Ministry of National Education (which should concentrate more on the introduction of objective religions - without negating the subjective ones - does not achieve this). There is a gap that is too far. If subjective-normative and objective-specific approach in religious education have no close relationship between the two, and establish scientific dichotomy, there will be a serious consequence.

The new perspective for fiqh requires the renewal of the methods and approaches of religions that have established for centuries. The perspective promotes education that is sensitive to the various values of the new community that develops in international interactions between the worlds, ethnic groups, interfaith groups, and is careful with the development of thinking and the reality of interfaith relations at the local, regional and international levels. This new sensitivity is important to be built so that religious education and learning does not lose its relevance to the ongoing developments outside the curriculum and syllabus. The new religious or figh literature in the area of religious studies has been academically initiated by the approach of the phenomenology of religion.

In higher education institutions, the phenomenology approach to religious ideology is relevant to be implemented in learning activities. This approach seeks to facilitate a dialogue between a subjective and objective approach towards religious understanding. The bridge between the two religious' nuances by Abdullah (2006) is called religious inter subjectivity. Intersubjective religious methodology provides understanding on the beliefs of other groups and acknowledge the existence and right of each (subjective) life without reducing anything. This can support the efforts to eliminate rigid, exclusive truth claims and dogmatic in religious life.

Religious phenomenology taught in higher education should emphasize that there are common patterns (sawabit) and certain patterns (mutagayyirât). The struggles, indepth discussions and dialectics between the two will form new empathy and sympathy attitudes and views between various adherents of religion, interethnicism, interculturality towards new values of civility towards peaceful coexistence, integration between civilizations. If this can be realized in higher education through learning in each subject, the religious understanding approach can produce positive values in solving every problem faced by students and the nation as a whole. 
Religious phenomenology applies an approach of religious understanding which should be reflected on the integrative curriculum with an intersubjective approach by Abdurrahman Assegaf (2014). The implementation includes four levels: (1) integration at the philosophical level, (2) integration at the material level, (3) integration at the strategy level and approach, and (4) integration in the evaluation level.

The workings of religious phenomenology can be described as follows. First, intellectual selection of common patterns and unique patterns in the religion history and thought. In the experience of daily life people and society in general, it cannot deny the reality of religious diversity. Diversity and plurality are inevitable. Each follower of religion claims that their religion is the true. The fundamental structure in terms of subjectivity and religion has been described above with seven tendencies inherent therein. To reduce the tension between the various unilateral claims, the phenomenology of religion offers religious and intellectualrational concepts and approaches that can clearly distinguish sides that are considered permanent or general patterns that do not change. Second, epoche and elditic vision. Epoche is the ability of a person or group to sincerely refrain from issuing statements, expressions or statements that are detrimental, condescending or hurting other groups in any form. The desire to issue these statements is postponed before the statements and judgments of negative or positive aimed or directed at people or groups and community followers in the first postponed. Give curly brackets in layers sign, followed by other brackets and followed by next brackets and so on for various forms of information about the beliefs and beliefs of others from wherever the source. In other words, this Epoche technique, is to reduce uncontrolled involvement and mixed emotions and which cannot be accounted for publicly and rationally. Third, religious historicity. Religion phenomenology obtains valuable input from scientificallyoriented religious studies. It is not religious phenomenology if it does not use accurate data collected and found through in-depth research by various social-religious scientific approaches, both from the history of religions, religious sociology, psychology and anthropology of religion. The area of al-mutaghayyirat or particular or unique pattern can only be clearly understood if religious phenomenology wants to examine the data provided by these approaches. It is suspected that there are at least seven items that can be found in religious life. First, religious followers must perform or carry out certain activities on a regular, routine and repeated basis (ritual; worship); second, they believe in something (the system of faith, aqeedab or dogma) ; third, they respect and glorify leaders who are deemed to have authority (the Prophet, apostles, to the level of ulama as the heirs of the prophet); fourth, they respect the scriptures; fifth, they have a history of the struggle of the heroic founders and the continuation of the successor generation until the time of the coming generation now (date, genealogy); sixth, they have a code of ethics and a moral system that can be used as a reference for the behavior of their adherents (sharia, fiqh); and seventh; they are supported by strong institutional institutions (social, educational, political institutions). Again, this look and description can be sure that there is no religion that is all and congruent in the natural world. Each religion is unique. It is too rash and over-simulating if there is an assumption stating that all religions are the same. The claim is not supported by any convincing evidence academically. Even theological validity is doubtful. What equates to or more appropriately is called "resembling" between extended families. These different religions are belief systems and socio-religious systems that support their existence which, among others, are marked with the seven items described above. They can be added and subtracted in accordance with the development of research findings in the field. Herein lies the importance of a particular or unique pattern or al-mutagayyirat in religion. Here also lies the separation between the social approach to religion that is only satisfied with the externalities and the religion of religion. While the social science approach to religion always involves the postulation of factors 
inherent in the world religion. Fourth, verstehen. Human diversity is indeed inseparable from the factor of subjectivity. It is also known that there is a religious side that cannot be separated from its objectivity, which is only understood and obtained through intellectual ijtihad and sharp logic and sincere depth of insight. Religious phenomenology raises new requirements for world religions namely versethen. Contemporary religious studies which are expected to contribute to perpetual peace can only be achieved if there is a spirit of unity between different cultures and world civilizations, between different ethnicity and race. Fifth, empathy and sympathy. Humans must not despair, says the Qur'an. Solving religious problems must be continuously pursued especially by experts and leaders of religious elites. The completion of previous models that are no longer relevant needs to be reviewed and repaired and perfected. Religious approaches that are subjective and reach the objective level apparently cannot solve the religious problem. Perpetual peace and peace full coexistence is still difficult to achieve. Healthy religious concepts need to be sought together. Inclusive-partnership-dialog. The epoche and eldetic vision techniques, along with the other procedures, have not yet formed comprehensive efforts towards perpetual peace if they have not formed a new mentality and religious mindset. This mindset is more dialogical, partnership, participatory and inclusive. Through epoche and editic vision of human values such as charity (good deeds; willingness to do charity without conditional), compassion and other noble character, religious problem can be solved.

Religion is very meaningful for its adherents. The study of new era religions that are oriented towards achieving the intent - the meaning of peace, and religious studies which have practical implications for a life together that can lead adherents to respect and trust each other. the need should be even more pressing. Religious phenomenology wants to encourage and develop religious thought into a new era that enlightens all parties, both enlightening internal insiders and insiders and outsiders and socio-religious observers

\section{CONCLUSION}

The global reaction to radicalism on campuses in Indonesia is not the reaction of a liberal, permissive and inclusive attitude, but rather a moderate response. This is due to the integrative curriculum implemented in several universities which has a positive impact on the containment of radicalism on campus. The application of integrative curriculum in learning through four levels, namely the philosophical, the material, the strategy and approach, and the evaluation level. The curriculum offers the prospect's solution by channeling the energy of jihad into the spirit of taking part in building world civilization. Indeed, the harsh and extreme face of radical groups in the Middle East is encouraging people to look for an 'authentic' version of Islam. What is missing and less known about Islam is the drive for reasoning, intellectual training, research, observation and innovation. Radicalism in Islam causes the spirit of research and innovation to halt.

Islam is expected to make a positive contribution to world civilization today as happened in the past history, making it a blessing for the universe (rahmatan lil'alamiin). The integrative curriculum that produces moderate religious understanding can also be accommodated by developing a virtual campus. Academic collaboration and joint research in innovation are then inevitable. Cooperation, dialogue and knowledge exchange lead to mutual respect and a peaceful global community. Integrative curriculum has been applied by a few universities. The curriculum has given a new nuance in solving religious problem among students in terms of how they should think and act. This study would recommend that the integrative curriculum can be implemented by all Islamic universities, even though it is carried out in stages. 


\section{BIBLIOGRAPHY}

Abdullah, M. A. (2010). Isamic Studies di Perguruan Tinggi Agama: Integrasi Interkoneksi. Yogyakarta: Pustaka Pelajar.

Abdullah, M. A. (ed.). 2004. Integrasi Sains-Islam: Mempertemukan Epsistemologi Islam dan Sains, Yogyakarta: Pilar Religia-SUKA Press.

Abdullah, M. A. (ed.). (2007). Islamic Studies dalam Paradigma Integrasi-Interkoneksi: Sebuah Antologi. Yogyakarta: SUKA Press.

Akhmadi, A. (2019). "Moderasi Beragama dalam Keragaman Indonesia Religious Moderation in Indonesia's Diversity". Jurnal Diklat Keagamaan, 13(2), 45-55. Retrieved from https://bdksurabaya.e-journal.id/bdksurabaya/article/view/82

Aseri, F., et al. (2015). "Radikalisme Islam di Kalangan Mahasiswa Perguruan Tinggi Negeri di Banjarmasin". Tashwir, 3(6), 175-197.

Asrori, A. (2015). "Radikalisme di Indonesia: Antara Historisitas dan Antropositas", Kalam: Jurnal Studi Agama dan Pemikiran Islam. (9)2, 253-268. https://doi.org/10.24042/klm.v9i2.331

Assegaf, A. R. (2011). Filsafat Pendidikan Islam: Paradigma Baru Pendidikan Hadhari Berbasis Integratif-Interlconektif. Jakarta: PT Radja Grafindo.

Assegaf, A. R. (2013). Aliran Pemikiran Pendidikan Islam: Hadharah Keilmuan Tokoh Klasik Sampai Modern. Jakarta: PT Radja Grafindo Persada.

Assegaf, A. R. (2014). "Unsur-unsur Transformatif Pengembangan Kurikulum 2013" dalam Kata Pengantar Pengembangan Kurikulum PAL Yogyakarta: Pascasarjana UIN Sunan Kalijaga.

Azra, A. (1999). Menuju Masyarakat Madani: Gagasan, Fakta dan Tantangan. Bandung: PT Remaja Rosda Karya Bandung.

Azra, A. (2005). Reintegrasi Ilmu-ilmu dalam Islam”. Zainal Abidin Bagir (ed.), Integrasi Ilmu dan Agama: Interpretasi dan Aksi, Bandung: Mizan.

Behr, I. V., et al. (2013). "Radicalisation in the Digital Era: The Use of the Internet in 15 Cases of Terrorism and Extremism". NCJ Number: 244529. Retrieved from http://www.ncjrs.gov/App/publications/abstract.aspx?ID=266610

Bötticher, A. (2017). "Towards Academic Consensus Definitions of Radicalism and Extremism", Perspectives on Terrorism. 11(4), 73-77. Retrieved from https://www.jstor.org/stable/26297896?seq=1\#metadata_info_tab_contents

Crawford, B. (2001). "Politik Identitas: Sebuah Pendekatan Kelembagaan". Jurnal Gerbang, IV $(10)$.

Fernando, R. \& Carola G. (2018). Moroccans and the second generation among Jihadists in Spain. Elcano Royal Institute, June 27.

Hasani, I., \& Bonar, T. N. (2012). Dari Radikalisme Menuju Terorisme. Jakarta: Pustaka Masyarakat Setara.

Hassan, G. S. (2013). "Radical Islam/Islamic Radicalism: Towards a Theoretical Framing", 14. Retrieved from http://www.researchgate.net/profile/Gubara_Hassan/

Kementerian Agama Republik Indonesia. (2019). Moderasi Beagama. Jakarta: Badan Litbang dan Diklat Kementerian Agama RI.

Khamdan, M. (2015). "Rethinking Deradikalisasi: Konstruksi Bina Damai Penanganan Terorisme ", ADDIN, 9(1), 181-204. http://dx.doi.org/10.21043/addin.v9i1.612

Laisa, E. (2014). "Islam dan Radikalisme". Islamuna. 1(1). 1-18. http://dx.doi.org/10.19105/islamuna.v1i1.554

Mubarok, M. Z., \& Hamid, A. F. A. (2018). "The Rise of Radicalism and Terrorism in Indonesia and Malaysia". RISEA: Review Journal of Southeast Asia, 1(1), 29-43. Retrieved from http://journal.uinjkt.ac.id/index.php/risea/article/view/9645 
Muchith, M. S. (2016). "Radikalisme dalam Dunia Pendidikan". ADDIN, 10(1), 163-180. http://dx.doi.org/10.21043/addin.v10i1.1133

Muzakki, A. (2014). "The Roots, Strategies, and Popular Perception of Islamic Radicalism in Indonesia". Journal of Indonesian Islam, 08 (01), 22. http://dx.doi.org/ 10.15642/JIIS.2014.8.1.1-22 publications.

Rahmatullah, Y. (2017). "Radicalism, Jihad and Terror". Al Albab, 6(2), 157-178. http://dx.doi.org/ 10.24260/alalbab.v6i2.731

Rink, A. \& Sharma, K. (2018). "The Determinants of Religious Radicalization: Evidence from Kenya". Journal of Conflict Resolution. 62(6), 229-1261. https://doi.org/10.1177/0022002716678986

Robingatun. (2017). "Radikalisme Islam dan Ancaman Kebangsaan”. Empirisma. 26(1), $97-$ https://doi.org/106. 10.30762/empirisma.v26i1.684

Rustam, E., Hanifah, N., Kanro, B. (2018). "De-radicalization in the Implementation of Islamic Education Curriculum in SMA Masamba South Sulawesi”. Dinamika Ilmu. 18(2), 271-283. https://doi.org/10.21093/di.v18i2.1338

Sadiah, D. (2018). "Strategi Dakwah Penanaman Nilai-nilai Islam dalam Menangkal Paham Radikalisme di Kalangan Mahasiswa". Anida: Aktualisasi Nuansa Ilmu Dakwah. 18(2). 219-236. https://doi.org/10.15575/anida.v18i2.5064

Saifuddin. (2011). "Radikalisme Islam di Kalangan Mahasiswa: Sebuah Metamorfosa Baru". Analisis, 11(1), 17-32. https://doi.org/10.24042/ajsk.v11i1.605

Sarie, F. \& Mariamah. (2013). "Keberhasilan Semu Deradikalisasi di Indonesia", GLOBAL, 15(2), 137-164. https://doi.org/10.7454/global.v15i2.34

Schoeck A. W. et. al., (2015). The Rise of Religious Radicalism in the Arab World: Significance, Implications and Counter-Strategies. Amman: Friedrich Ebert Stiftung.

Suharto, T. \& Assegaf, J. (2014). "Membendung Arus Paham Keagamaan Radikal di Kalangan Mahasiswa PTKIN”. Al-Tabrir. 14(1), 157-180. https://doi.org/10.21154/altahrir.v14i1.72

Tahir, M. (2015). "The Role of Universities in The Overcoming and Prevention of Terrorist Radicalism and ISIS in The Campus in West Nusa Tenggara". Tasâmuh, 13(1), 59-68. Retrieved from https://journal.uinmataram.ac.id/index.php/tasamuh/article/view/187

Taufik, A. S. (2019). "Teaching Methods in Pesantren to Tackle Religious Radicalism". Jurnal Pendidikan Islam, 5 (2). https://doi.org/189-200. 10.15575/jpi.v5i2.6178

Tina, R. M. (2017). Promotion and Implementation of Global. Citizenship Education in Crisis Situations. UNESDOC Digital Library. Programme and meeting document.

Veldhuis, T. \& Staun, J. (2009). Islamist Radicalisation: A Root Cause Model. The Hague: Netherlands Institute of International Relations Clingendael.

Yusar. (2016). "The Youth, The Sciences Students, and Religious Radicalism”. Al-Ulum. 16(2), 330-347. https://doi.org/10.30603/au.v16i2.154 